\title{
Evaluation the Efficacy of Plant Extracts and Bio-agents against Macrophomina phaseolina in vitro
}

\author{
Mohit Kumar*, Data Ram Kumhar, Shankar Lal Godara, Surbhi Garg \\ Department of Plant Pathology, College of Agriculture, Swami Keshwanand Rajasthan \\ Agricultural University, Bikaner-334006, Rajasthan, India \\ *Corresponding author
}

Keywords

Mungbean, Plant extract, Bio-agent,

Macrophomina

phaseolina,

Inhibition, Mycelial

Article Info

Accepted:

26 April 2020

Available Online:

10 May 2020

\section{A B S T R A C T}

The present study was carried to evaluate the efficacy of various plant extracts and bio-agents against Macrophomina phaseolina. It is a devastating disease in green gram growing area of Rajasthan. In vitro evaluation of bio-agents and seven plants extract (Datura stramonium, Allium sativum, Zingiber officinalis, Lepticium sparticum, Azadirachta indica, NSKE and Allium cepa), revealed that maximum growth inhibition of Macrophomina phaseolina was recorded in Allium sativum followed by Zingiber officinalis at 5\%,10\% and $15 \%$ concentrations. Among the concentrations $15 \%$ was most effective. Trichoderma harzianum was the most promising antagonist against Macrophomina phaseolina among the different fungal and bacterial antagonists, followed by Trichoderma viride and Pseudomonas fluorescens. The Present study was planned to evaluate the efficacy of bio-agents and plant extracts against Macrophomina phaseolina causing dry root rot of green gram.

\section{Introduction}

Mungbean/green gram [Vigna radiata (L.) Wilczek] is one of the most important pulse crop. It is grown in almost all parts of the country. In India, It is third most important pulse crop after chickpea and pigeonpea and covers an area about 29.36 lakh ha with production of 13.90 lakh tonnes (Anonymous 2014-15), In India, Mungbean is mainly grown in the states of Rajasthan, Maharastra, Madhya Pradesh, Orissa, Andhra Pradesh, Tamil nadu, and Uttar Pradesh. In Rajasthan, the total area under Cultivation of mungbean is 13.68 lakh ha with the annual production of 6.02 lakh tonnes with the productivity of $441 \mathrm{~kg} / \mathrm{ha}$ (Anonymous, 2015-16). In Rajasthan Mungbean is grown in Jaipur. Bhilwara. Bharatpur. Sriganganagar, Bikaner, Jodhpur, Kota, Ajmer and Udaipur district. 
It has proved to be an ideal crop for spring and summer/kharif season. Mungbean belongs to family leguminosae and sub family papilionaceae. Mungbean is an excellent source of high quality protein. It is consumed in different ways as dal, halwa, snacks and so many other preparations. Ascorbic acid (vitamin-C) is synthesized in sprouted seeds of mungbean. The amount of riboflavin and thiamine is also increased in sprouted seeds being a leguminous crop, it has the capacity to fix atmospheric nitrogen through symbiotic nitrogen fixation. It is also used as green manure crop.

Mungbean is prove to different fungal diseases, among them dry root rot incited by Macrophomina phaseolina is a soil borne pathogen. Macrophomina phaseolina survives in/on seed and persisted in the soil in the form of black sclerotia which are produced in large number on infected host tissues and are subsequently dispersed in soil during tillage operations.

The fungicides presently recommended to manage these diseases provide protection for limited period. The continuous use of traditional fungicides may cause bioaccumulation of the toxic residues besides giving rise to resistant strains. Increased public concern about pesticide utilization and the health hazards necessitates the exploitation of alternative methods of disease control. Now a day's research on disease management all over the world is mostly towards biological control or application of combined treatment of bioagents, fungicide and also biofertilizer. In the last three decades, a lot of researches have been carried out on the antagonistic nature of several fungal and bacterial biocontrol agents (Papavizas, 1985). Blakeman and Fokkema (1982) reported that Trichoderma species are the well-known antagonists, particularly in the soil and that they are involved in competition, antibiosis and hyperparasitic interactions, which makes them the most effective biocontrol agents even on foliar surfaces.

\section{Materials and Methods}

All the experiments were conducted under in vitro condition during 2016-17 at Department of Plant Pathology, College of Agriculture, Bikaner (Rajasthan).

\section{Plant extract}

Different plant extracts were tested for their efficacy against Macrophomina phaseolina in vitro (Table 1).

\section{Preparation of plant extract}

Selected plants were collected from the surrounding areas of Bikaner, and washed thoroughly with tap water and air dried. One hundred gram of plant part was grind using pestle and mortar by adding equal amount $(100 \mathrm{ml})$ of sterilized distilled water (1: 1 , $\mathrm{w} / \mathrm{v})$. The pulverized mass was squeezed through the cheese cloth and the extracts were centrifuged at $10000 \mathrm{rpm}$ for 5-10 minutes and used as stock solution. To study the antifungal property of plant extracts, poisoned food technique (Nene and Thapliyal, 1993) was adopted.

The stock solutions of different botanicals (5, 10 and $15 \%$ ) were mixed with 95,90 , and 85 $\mathrm{ml}$ of PDA media, respectively so as to get 5, 10 and 15 per cent concentrations and sterilized. Twenty $\mathrm{ml}$ of such medium was poured under aseptic conditions into sterile Petri plates allowed to solidify. Mycelial discs $(5 \mathrm{~mm})$ were cut out using sterile cork borer from periphery of actively growing culture of M. phaseolina and one such disc was placed on the centre of each Petri plate. The treatments were replicated thrice. Control was 
maintained by growing the pathogen on PDA plates without plant extracts. Plates were incubated at room temperature $\left(28+2^{\circ} \mathrm{C}\right)$ for 7 days and radial growth was taken at the time when maximum growth occurred in the control plates.

\section{Formula}

$$
\text { Per cent inhibition }=\frac{\mathrm{C}-\mathrm{T}}{\mathrm{C}} \times 100
$$

$\mathrm{C}=$ Mycelial growth of $M$. phaseolina in control (mm)

$\mathrm{T}=$ Mycelial growth of $M$. phaseolina in presence of plant extracts $(\mathrm{mm})$

\section{In vitro evaluation of antagonistic potential of test bio-agents}

The selected antagonists were purified and their antagonistic activities were tested against $M$. phaseolina in vitro as described below.

\section{Evaluation of antagonistic potential of fungal antagonists}

Dual culture technique (Dennis and Webster, 1971) was followed in order to ascertain the antagonistic capacity of Trichoderma spp. and other fungal antagonists. One mycelial disc (5 $\mathrm{mm}$ diameter) of each of the pathogen and antagonist was kept on the surface of potato dextrose agar medium in Petri dishes at $5 \mathrm{~cm}$ apart.

The inoculated Petri dishes were incubated at $28 \pm 2{ }^{0} \mathrm{C}$ for 7 days. Three replications were kept for each fungal antagonist. In case of control, the Petri dishes were inoculated with mycelial disc of the test pathogen only.

The mycelial growth of test pathogen was measured after 4 days of inoculation. Per cent growth inhibition was calculated by following formula as: (Vincent., 1927)

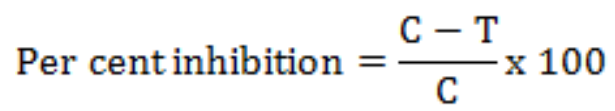

$\mathrm{C}=$ Mycelial growth of $M$. phaseolina in control (mm)

$\mathrm{T}=$ Mycelial growth of $M$. phaseolina in presence of antagonist (mm).

Evaluation of antagonistic potential of bacterial antagonists

Paper disc inoculation method was followed in order to test the antagonistic capacity of bacterial antagonists. Stock cultures of $P$. fluorescens and B. subtilis were streaked on Pseudomonas agar fluorescens and nutrient agar media slants respectively and incubated at $28 \pm 1^{0} \mathrm{C}$ for 8 hours.

Ten $\mathrm{ml}$ sterilized distilled water was added to each slant containing the fresh colony of respective bacterial antagonists and suspension was prepared by scrapping the bacterial growth with the help of sterilized inoculating needle.

The suspension was transferred to sterilized Petri dishes. Sterilized filter paper discs (5 $\mathrm{mm}$ diameter) were dipped in respective bacterial suspension. Four such inoculated discs were placed in opposite directions on the surface of nutrient-agar media in Petri dishes.

Mycelial discs (5 $\mathrm{mm}$ diameter) taken from periphery of actively growing culture of $M$. phaseolina raised on nutrient-agar media was placed at the center of Petri dishes containing the inoculated paper discs In case of control, the Petri dishes were inoculated with mycelial discs of the test pathogen only.

Three replications were kept for each bacterial antagonist. The inoculated Petri dishes were incubated at $28 \pm 1^{\circ} \mathrm{C}$ in BOD incubator. Mycelial growth of $M$. phaseolina 
was recorded after 7 days of incubation. The inhibition of mycelium growth by the respective bacterial antagonists was calculated by using the following formula (Vincent, 1927)

$$
\text { Per cent inhibition }=\frac{\mathrm{C}-\mathrm{T}}{\mathrm{C}} \times 100
$$

$\mathrm{C}=$ Mycelial growth of $M$. phaseolina in control (mm)

$\mathrm{T}=$ Mycelial growth of $M$. phaseolina in presence of antagonist (mm)

\section{Results and Discussion}

Effect of plant extracts on growth of Macrophomina phaseolina under in-vitro

The results revealed that all the plant extracts at $5 \%, 10 \%$ and $15 \%$ concentrations were significantly inhibited the growth of the fungus as compared to the control. Among the above tested concentrations, $15 \%$ concentration is most effective in inhibiting the growth of fungus as compared to $10 \%$ and $5 \%$. At $15 \%$ concentration of plant extract, the Allium sativum extract proved significantly superior $(82.00 \%)$ in checking the fungal growth over the rest. The next best in order of merit was Zingiber officinalis $(61.11 \%)$ (Table 3).

The extracts of Allium cepa (55.50\%), Datura stramonium (50.00\%), NSKE (44.40) and Azadirachta indica leaf extract (38.80\%) were effective against the pathogen while Lepticium sparticum (27.00\%) was comparatively less effective. The results indicated that the Allium cepa extract gave maximum inhibition followed by extract of Zingiber officinalis.

Findings of our experimental are very much similar to findings of S.V. Magar et al., (2011), they evaluated that the efficacy of plant extracts against leaf blight of green gram incited by Macrophomina phaseolina
(Tassi) Goid and revealed that the bulb extracts of Allium sativum was most effective in inhibiting the growth of the test fungus followed by Zingiber officinalis and Allium cepa.

Dhingani et al., (2013) observed that among the plant extracts, Allium sativum extract was found most effective in reducing root rot incidence followed by Azadirachta indica leaf extract. Meena et al., (2014) also observed that garlic extract found most effective in reducing the growth of Macrophomina phaseolina in vitro.

Lalita Lakhran and R.R. Ahir (2018) observed in six plant extracts, garlic extract was found most effective in reducing root rot incidence followed by neem leaf extract.

Savaliya et al., (2015) reported the efficacy of various botanicals against Macrophomina phaseolina (Tassi.) Goid causing root rot of sesame. The phyto extracts of nine plant species were evaluated in vitro by poisoned food technique against $M$. phaseolina. The extract of garlic cloves (Allium sativum L.) was proved excellent with maximum inhibiting $(77.65 \%)$ of mycelial growth and scanty sclerotial formation followed by onion bulb extract (Allium cepa L.) (63.98\%), while least growth inhibition (32.34\%) was recorded in ginger rhizome extract. These findings corroborated with our findings that plant extracts is effective in inhibiting the growth of Macrophomina phaseolina in vitro.

\section{Efficacy of bio-agents against} Macrophomina phaseolina under in vitro

The antagonists isolated from rhizosphere of healthy mungbean fields were tested for their antagonistic reactions against Macrophomina phaseolina. All the isolated antagonists were significantly superior in inhibiting the growth of test fungus over the control. Microorganisms which developed well 
marked zones of inhibition on agar plates comprised two fungi viz., Trichoderma harzianum and T. viride. Maximum growth inhibition was recorded in $T$. harzianum (73.33\%) followed by $T$. viride $(64.44 \%)$, out of two bacteria, maximum growth inhibition was recorded in Pseudomonas fluorescens (46.66\%), and this was at par with Bacillus subtilis $(38.88 \%)$. The fungal antagonists $T$. harzianum and $T$. viride and two bacterial antagonists i.e. Pseudomonas fluorescens and $B$. subtilis significantly inhibited the mycelial growth of M. phaseolina in vitro (Table 2 and 4 ).

These findings very much similar to findings of Priyanka Meena et al., (2017), they observed that Trichoderma and other species isolated from infested soil were tested for their antagonism to Macrophomina phaseolina on Czapek's dox agar medium in Petri dishes. Four fungi Aspergillus niger, Trichoderma atroviride, T. harzianum, T.viride gave distinct antagonistic reactions, showing stunting of Macrophomina phaseolina colony and a clear cut inhibition zone between colonies of antagonist and the pathogen. Trichoderma harzianum was most effective among all antagonists in reducing charcoal rot of fenugreek followed by Trichoderma viride, Trichoderma atroviride and Aspergillus niger.

Bimla and Gaur (2016) observed that three fungi and one bacterium viz., T. harzianum, T. viride, T. atroviride and Bacillus sp. isolated from soil of crop fields were tested in vitro for their antagonistic activity against eight isolates of Macrophomina phaseolina on Czapek's dox agar medium. Inhibition of the mycelium growth (\%) of pathogen by $T$. harzianum, T. viride, $T$. atroviride and Bacillus sp. varied from 56.53 to $70.87,53.56$ to $64.88,50.05$ to 62.06 and 45.95 to 55.86 . $T$. harzianum inhibited maximum mycelial growth of all the isolates followed by $T$. viride, T. atroviride and Bacillus sp. in vitro condition. These findings very much similar to our findings that bio-agents are very much effective in inhibiting the growth of Macrophomina phaseolina.

Table.1 Name of plant extracts tested against Macrophomina phaseolina (in vitro)

\begin{tabular}{|c|c|c|}
\hline Common Name & Botanical Name & Part used \\
\hline Datura & Datura stramonium & Leaf \\
\hline Garlic & Allium sativum & Clove \\
\hline Ginger & Zingiber officinalis & Rhizome \\
\hline Kheep & Lepticium sparticum & Stem \\
\hline Neem leaf & Azadirachta indica & Leaf \\
\hline NSKE & Azadirachta indica & Seed \\
\hline Onion & Allium cepa & Bulb \\
\hline
\end{tabular}

Table.2 Name of Bio-agent tested against Macrophomina phaseolina (in vitro)

\begin{tabular}{|c|}
\hline Bio-agent \\
\hline Trichoderma harzianum \\
\hline Trichoderma viride \\
\hline Pseudomonas fluorescens \\
\hline Bacillus subtilis \\
\hline
\end{tabular}


Table.3 Efficacy of plant extracts against $M$. phaseolina under in vitro

\begin{tabular}{|c|c|c|c|c|c|c|}
\hline \multirow[b]{3}{*}{ Treatment } & \multicolumn{6}{|c|}{ Per cent inhibition of mycelial growth } \\
\hline & \multicolumn{2}{|c|}{$5 \%$ Conc. } & \multicolumn{2}{|c|}{$10 \%$ Conc. } & \multicolumn{2}{|c|}{$15 \%$ Conc. } \\
\hline & $\begin{array}{c}\text { Mycelial } \\
\text { Growth } \\
\text { (mm) }\end{array}$ & $\begin{array}{l}\text { Growth } \\
\text { Inhibition } \\
(\%)\end{array}$ & $\begin{array}{c}\text { Mycelial } \\
\text { Growth } \\
(\mathbf{m m})\end{array}$ & $\begin{array}{l}\text { Growth } \\
\text { Inhibition } \\
\text { (\%) }\end{array}$ & $\begin{array}{c}\text { Mycelial } \\
\text { Growth } \\
(\mathbf{m m})\end{array}$ & $\begin{array}{l}\text { Growth } \\
\text { Inhibition } \\
\text { (\%) }\end{array}$ \\
\hline $\begin{array}{c}\text { Datura stramonium } \\
\text { (Datura) }\end{array}$ & 60.00 & $\begin{array}{c}33.30 \\
(35.23)^{*}\end{array}$ & 54.00 & $\begin{array}{c}40.00 \\
(39.21)^{*}\end{array}$ & 45.00 & $\begin{array}{c}50.00 \\
(44.98)^{*}\end{array}$ \\
\hline $\begin{array}{l}\text { Allium sativum } \\
\text { (Garlic) }\end{array}$ & 55.00 & $\begin{array}{c}38.80 \\
(38.51)\end{array}$ & 40.00 & $\begin{array}{c}55.00 \\
(47.85)\end{array}$ & 16.00 & $\begin{array}{c}82.00 \\
(64.87)\end{array}$ \\
\hline $\begin{array}{l}\text { Zingiber officinalis } \\
\text { (Ginger) }\end{array}$ & 58.00 & $\begin{array}{c}35.50 \\
(36.55)\end{array}$ & 43.00 & $\begin{array}{c}52.22 \\
(46.25)\end{array}$ & 35.00 & $\begin{array}{c}61.11 \\
(51.39)\end{array}$ \\
\hline $\begin{array}{l}\text { Lepticium sparticum } \\
\text { (Kheep) }\end{array}$ & 88.00 & $\begin{array}{c}2.22 \\
(8.41)\end{array}$ & 80.00 & $\begin{array}{c}11.10 \\
(19.38)\end{array}$ & 65.00 & $\begin{array}{l}27.70 \\
(31.74)\end{array}$ \\
\hline $\begin{array}{c}\text { Azadirachta indica } \\
\text { (Neem leaf) }\end{array}$ & 75.00 & $\begin{array}{c}16.60 \\
(24.02)\end{array}$ & 68.00 & $\begin{array}{c}24.44 \\
(29.61)\end{array}$ & 55.00 & $\begin{array}{l}38.80 \\
(38.51)\end{array}$ \\
\hline NSKE & 65.00 & $\begin{array}{l}27.70 \\
(31.74)\end{array}$ & 57.00 & $\begin{array}{c}36.66 \\
(37.25)\end{array}$ & 50.00 & $\begin{array}{c}44.40 \\
(41.76)\end{array}$ \\
\hline $\begin{array}{l}\text { Allium cepa } \\
\text { (Onion) }\end{array}$ & 60.00 & $\begin{array}{c}33.30 \\
(35.23)\end{array}$ & 52.00 & $\begin{array}{c}42.22 \\
(40.51)\end{array}$ & 40.00 & $\begin{array}{c}55.50 \\
(48.13)\end{array}$ \\
\hline Control & 90.00 & - & 90.00 & - & 90.00 & - \\
\hline $\begin{array}{c}\text { S.Em } \pm \\
\text { CD }(\mathbf{P}=0.05) \\
\text { CV \% }\end{array}$ & & $\begin{array}{l}0.79 \\
2.30 \\
4.15\end{array}$ & & $\begin{array}{l}1.30 \\
3.92 \\
4.90\end{array}$ & & $\begin{array}{l}1.44 \\
4.25 \\
3.92\end{array}$ \\
\hline
\end{tabular}

*Figure in parentheses are angular transformed values

Table.4 Efficacy of bio-agents against Macrophomina phaseolina under in vitro

\begin{tabular}{|c|c|}
\hline Bio-agent & Per cent inhibition \\
\hline Trichoderma harzianum & $73.33(59.05)^{*}$ \\
\hline Trichoderma viride & $64.44(53.71)$ \\
\hline Pseudomonas fluorescens & $46.66(43.34)$ \\
\hline Bacillus subtilis & $38.88(38.78)$ \\
\hline Control & - \\
\hline S.Em \pm & 0.51 \\
CD P=0.05 & 1.56 \\
C.V $(\%)$ & 2.62 \\
\hline
\end{tabular}

*Figure in parentheses are angular transformed values

Thombre and Kohire (2018) tested seven fungal and two bacterial bioagents / antagonists evaluated in vitro were found antifungal / antagonistic against $M$. phaseolina. However, T. harzianum was found most effective and recorded significantly highest mycelial growth inhibition $(77.59 \%)$ of the test pathogen over untreated control. 
The second and third best bioagents / antagonists found were A. niger and T. viride which recorded mycelia inhibition of 68.17 and 65.46 percent, respectively. The antagonists $P$. fluorescens and $B$. subtilis was also found fungistatic and recorded 51.37 and 60.90 percent mycelial inhibition, respectively. These findings very much similar to our findings that bio-agents are very much effective in inhibiting the growth of Macrophomina phaseolina.

Majumdar and Gaur (1996), Sethuraman et al., (1998), Desai and Kulkarni (2002), Gupta et al., (2003), Rani et al., (2009), Anis et al., (2010), Kaur et al., (2010), Magar et al., (2011), Kumari et al., (2012), Kumar et al., (2013), Doley and Jite (2012), Ramezani (2008), Lokesha and Benagi (2007), Kaswate et al., (2003) found that Trichoderma, Bacillus and Pseudomonas were antagonistic to Macrophomina phaseolina in their studies in vitro and confirming the our present findings.

\section{References}

Anis MM, Waseem Abbasi, Javed Zaki M. 2010. Bioefficacy of microbial antagonists against Macrophomina phaseolina on sunflower. Pak. J Bot. 42(1):2935-2940.

Anonymous, 2014-15. ICAR-Indian Institute of Pulses Research Kanpur, Annual Report 208017.

Anonymous, 2015-16. Directorate of Pulses Development, Annual Report 2016-17

Bimla; Gaur, V. K. 2016. Study of the isolation and antagonistic effect of microorganism viz., Trichoderma and Bacillus spp. against different isolates of Macrophomina phaseolina [Tassi] Goid. in vitro. Annals of Agri Bio Research. 21(2):144-148.

Blakeman JP, Fokkema NJ., 1982, Potential for biological control of plant diseases on the phylloplane. Annu Rev Phytopathol, 20:167-192.

Dennis C, Webster J., 1971. Antagonistic properties of species group of Trichoderma and hyphal interaction. Trans. British Mycol. Soc. 57:363-369.

Desai, SA., Kulkarni, S., . 2002. Antagonistic efficacy against Macrophomina phaseolina (Tassi) Goid through production of nonvolatiles by biocontrol agents. Karnataka $J$ Agric. Sci; 15(1):170-171.

Dhingani, J. C., Solanky, K.U., and Kansara, S.S., 2013, Management of root rot disease Macrophomina paseolina (Tassi.) Goid] of chickpea through botanicals and oil cakes. The Bioscan. 8(3): 739-742.

Doley, K., and jite, P.K., 2012. In-vitro efficacy of Trichoderma viride against Sclerotium rolfsii and Macrophomina phaseolina. Not. Sci.Biol.4(4): 39-44.

Gupta, O., Jharia, HK., Sharma, ND., 2003, Bacillus subtilis: an effective antagonist of Rhizoctonia bataticola (Taub.) Butler causing dry root rot of chickpea. Indian $J$ Pulses Res. 16(1):42-46.

Kaswate, N. S., Shinde, S. S., and Rathod, R. R., 2003. Effect of biological agents against different isolates of Rhizoctonia bataticola (Taub.) Butler in vitro. Ann. Pl. Physiol. 17(2): 167-168.

Kaur, Sarbjeet., Singh, Narinder., Sandhu, PS., 2010. In vitro evaluation of Trichoderma viride and $T$. harzianum against Macrophomina phaseolina, causing charcoal root rot of sunflower. Pl. Des. Res. 25(1):79.

Kumar, M., Gaur, V. K. and Kant, 2013. Evaluation of antagonists to Macrophomina phaseolina causing dry root rot in Mothbean. Ann. Pl. Protec. Sci. 21(1): 163166.

Kumari, R., Shekhawat, KS., Gupta, R., Khokhar, MK., 2012. Integrated Management against Root-rot of Mungbean [Vigna radiata (L.) Wilczek] incited by Macrophomina phaseolina. J Pl. Pathol. Microbio. 3:136.

Lakhran Lalita and Ahir R.R. 2018. In-vivo evaluation of different fungicides, plant extracts, bio-control agents and organics amendments for management of dry root rot of chickpea caused by Macrophomina phaseolina. Legume Research, DOI: 10.18805/LR-3939.

Lokesha, N. M., and Benagi, V. I., 2007. Biological Management of Pigeonpea Dry 
Root Rot Caused by Macrophomina phaseolina. Karnataka J. Agric. Sci. 20(1): 54-56.

Magar, SV., Kadam, JJ., Rite, SC, Thaware, DS., Potphode, PD., 2011. Exploration of plant extracts and fungal antagonists against Macrophomina phaseolina (Tassi.) Goid causing leaf spot in green gram. International Journal of Plant Protection.4(1):30-33

Majumdar, VL, Gour, H.N., 1996. Effects of biocontrol agents on the growth of Macrophomina phaseolina, the incitant of blight of moth bean. Indian J Mycol. Pl. Pathol. 26(2): 202-203.

Meena Priyanka., Gaur, V. K., Meena, M. K., Meena Ashok and Singh Veer. 2017. Antagonistic activity of some selected strains of fungus and bacteria against the causal agents of charcoal rot (Macrophomina phaseolina) in fenugreek and their application in green house conditions. Environment and Ecology. 35(3):1975-1978.

Meena, P. N., Tripathi, A. N., Gotya, B. S. and Satpathy, S., 2014. Bio-efficacy of phytoextracts and oil cakes on Macrophomina phaseolina (Tassi) causing stem rot disease of jute, Corchorus spp. J.Applied Natural Sci. 6 (2):530-533.

Nene, YL, Thapliyal, PN., 1993. Evaluation of fungicides. In: Fungicides in Pl. Dis. Control, (3rd ed.) Oxford IBH Pub. Co.,
New Delhi. 531-532.

Papavizas, G.C., 1985. Trichoderma and Gliocladium biology, ecology and potential for bio control. Ann.Rev. Phytopath. 23: 23-54.

Ramezani, H., 2008. Biological control of root rot of eggplant caused by Macrophomina phaseolina. American Eurasain j. Agric. Env. Sci., 4(2):218-220.

Rani, SU., Udayakumar, R., Christopher, DJ., 2009. Bio-efficacy of plant extracts and bio- Control agents against Macrophomina phaseolina. Ann. Pl. Prot. Sci. 17(2):389393.

Savaliya, V. A., Bhaliya, C. M., Marviya, P. B, and Akbari, L. F. 2015. Evalution of phytoextracts against Macrophomina phaseolina (Tassi) Goid causing root rot of sesame. J. Biopest. 8(2):116-119.

Sethuraman, K., 1998. In vitro screening of Trichoderma spp. against Macrophomina phasolina causing root rot of sesamum. Madras Agric. J. 85(10-12):698-699.

Thombre, BB., and Kohire, OD., 2018. In vitro bio-efficacy of bioagents and botanicals against Macrophomina blight of mungbean caused by Macrophomina phaseolina (Tassi) Goid. International Journal of Chemical Studies. 6(2): 3063-3066.

Vincent JM. 1927. Distortion of fungal hyphae in the presence of certain inhibitors, Nature, 159-180.

\section{How to cite this article:}

Mohit Kumar, Data Ram Kumhar, Shankar Lal Godara, Surbhi Garg. 2020. Evaluation the Efficacy of Plant Extracts and Bio-agents against Macrophomina phaseolina in vitro. Int.J.Curr.Microbiol.App.Sci. 9(05): 3474-3481. doi: https://doi.org/10.20546/ijcmas.2020.905.412 